\title{
1 A novel technique including GPS radio occultation for detecting and
}

\section{2 monitoring volcanic clouds}

3 Riccardo Biondi ${ }^{1}$, Andrea Steiner ${ }^{1}$, Gottfried Kirchengast ${ }^{1,2}$, Hugues Brenot ${ }^{3}$, Therese Rieckh ${ }^{1}$

$4 \quad{ }^{1}$ Wegener Center for Climate and Global Change (WEGC), University of Graz, Graz, Austria

$5{ }^{2}$ Institute for Geophysics, Astrophysics, and Meteorology/Institute of Physics, University of

6 Graz, Graz, Austria

$7 \quad{ }^{3}$ Belgian Institute for Space Aeronomy (BIRA-IASB), Brussels, Belgium

Correspondence to: R. Biondi (riccardo@biondiriccardo.it)

Abstract

The volcanic cloud top altitude and the atmospheric thermal structure after volcanic eruptions are studied using Global Positioning System (GPS) Radio Occultation (RO) profiles co-located with independent radiometric measurements of ash and $\mathrm{SO}_{2}$ clouds. We use the GPS RO data to detect volcanic clouds and to analyze their impact on climate in terms of temperature changes. We selected about 1300 GPS RO profiles co-located with two representative eruptions (Puyehue 2011, Nabro 2011) and found that an anomaly technique recently developed for detecting cloud tops of convective systems can also be applied to volcanic clouds. Analyzing the atmospheric thermal structure after the eruptions, we found clear cooling signatures of volcanic cloud tops in the upper troposphere for the Puyehue case. The impact of Nabro lasted for several months, suggesting that the cloud reached the stratosphere, where a significant warming occurred. The results are encouraging for future routine use of RO data for monitoring volcanic clouds.

\section{Introduction}


Explosive volcanic eruptions produce large ash clouds and inject huge amounts of gas, aerosol, and ash into the troposphere, which can even reach into the stratosphere (Bourassa et al., 2012, 2013; Fromm et al., 2013, 2014). Major volcanic eruptions can cause short-term climate change (Robock, 2013) if sulfur dioxide $\left(\mathrm{SO}_{2}\right)$ is injected into the stratosphere, forming sulfate aerosols with a long residence time (about 1 to 3 years). The effect is a global warming of the stratosphere and a cooling of the troposphere as was observed for the Mount Pinatubo eruption (Robock, 2000). The impacts largely depend on the total mass erupted, the altitude reached by the ash and $\mathrm{SO}_{2}$ clouds, the location of the volcano, and the extent of the dispersion due to atmospheric circulation. Under favorable atmospheric conditions volcanic ash clouds can spread over thousands of kilometers in just a few hours.

Ash clouds are a threat for aviation transport (Prata, 2008), since they can damage the aircraft engines even at large distances from the eruption. In 2010, the Eyjafjöll eruption in Iceland (Stohl et al., 2011) generated the largest air traffic shutdown since the Second World War with an estimated loss of about 3 billion dollars for the airline industry and with major effects on social and economic activities. Research attention focused on the improvement of detection and monitoring of volcanic ash clouds, which had already been advocated by Tupper et al. (2004). The ESA-EUMETSAT workshop on "Monitoring volcanic ash from space" (Zehner, 2010) provided a list of recommendations stating that "Studies should be made of potential new satellites and instruments dedicated to monitoring volcanic ash plumes and eruptions" and highlighting the difficulty to monitor such events with the current knowledge.

Observing the density of the ash cloud is one of the major challenges, since values larger than $2 \mathrm{mg} / \mathrm{m}^{3}$ are considered dangerous for aircraft engines. This parameter can only be detected by flying into the cloud with all related risks. The ejected mass of the eruption is fundamentally related to the maximum height reached by a volcanic plume (Settle, 1978). This volcanic cloud top altitude can be detected with different techniques (ground based, in situ, satellite), but typically with quite low accuracy.

Knowledge of the cloud top altitude is essential, however, to provide information on ash-free altitude regions for air traffic and on potential overshooting and spread of $\mathrm{SO}_{2}$ into the stratosphere, which impacts climate. The discrimination of ash clouds from other types of clouds is challenging, wherefore Tupper et al. (2004) state " a reliable detection system cannot be 
dependent on the meteorological conditions and it is necessary to have a weather independent warning capacity". Along these lines the potential of the relatively new satellite technique of radio occultation (RO) based on Global Positioning System (GPS) signals, or more generally Global Navigation Satellite System (GNSS) signals, comes into play (Biondi et al., 2012, 2013). In this study we provide an assessment of the potential capacity of the RO technique for volcanic cloud detection and monitoring. Section 2 provides an overview of the available observing techniques and introduces the potentially unique role of RO data. Section 3 then summarizes the data sets used and section 4 the study cases (three example eruptions) and methods. Subsequently we discuss the results in section 5 and draw conclusions in section 6 .

\section{Volcanic Cloud Observing Techniques}

Volcanic ash clouds are currently monitored by the International Airways Volcano Watch (IAVW) using a combination of ground-based sensors, satellite sensors, and aircraft measurements, but each of these methods has some temporal, spatial or technological limitation. According to the International Union of Geodesy and Geophysics (IUGG) only about $50 \%$ of the World's volcanoes that currently threaten air operations have any sort of ground-based monitoring (IUGG, 2010). The greatest danger for the air traffic is the time just after the eruption when no warnings are available, models are not reliable, and atmospheric observations are sporadic. The vertical resolution of most satellite data is very coarse for monitoring such kind of phenomena and thus there is an urgent need to gather information on the vertical structure of evolving volcanic clouds (Zehner, 2010).

Geostationary satellite data (e.g., the Spinning Enhanced Visible and InfraRed Imager - SEVIRI) and polar satellite data (e.g., the Advanced Very High Resolution Radiometer - AVHRR, and the Moderate-Resolution Imaging Spectroradiometer - MODIS) are used for detecting and monitoring volcanic clouds (Holasek and Self, 1995; Woods et al., 1995; Prata, 2008; Clarisse et al., 2012; Theys et al., 2013), but they cannot profile the atmosphere vertically and measurements are affected by the presence of other types of clouds. Research aircraft are very useful for getting information about the ash extent and concentration. They provide accurate products, but they are not operational, the spatial coverage is limited, and technical limitations are the same as for commercial aircraft, i.e., they cannot fly where the ash concentration is too 
high. Ground-based instruments such as lidars (Sawamura et al., 2012), radars (Harris and Rose, 1983), and cameras are also important for monitoring the eruptions, but they are too sparse and with limited spatial coverage.

Many techniques have been developed for detecting ash clouds (Prata, 2008; Clarisse et al., 2012) and $\mathrm{SO}_{2}$ clouds (Prata, 2008; Theys et al., 2013) relying on different satellite measurements with different resolutions such as the Global Ozone Monitoring Experiment (GOME-2), the Ozone Monitoring Instrument (OMI), the Infrared Atmospheric Sounding Interferometer (IASI), MODIS, and the Atmospheric InfraRed Sounder (AIRS). The CloudAerosol Lidar with Orthogonal Polarization (CALIOP) on board of the Cloud-Aerosol Lidar and Infrared Pathfinder Satellite Observations (CALIPSO) satellite is able to profile the volcanic ash cloud with very high vertical resolution (Vernier et al., 2013), but the temporal resolution is not adequate for following the development of the plume and sometimes the discrimination of ash plumes from other type of clouds is problematic.

The GNSS RO technique is highly complementary to these other systems, enabling measurement of atmospheric density and temperature structure in nearly any meteorological weather conditions, during day and night, with global coverage, and with high vertical resolution and high accuracy (e.g., Anthes et al., 2011; Steiner et al., 2011). Several GNSS RO missions are operating at present, providing vertical atmospheric profiles with good global coverage in space and time, like the US/Taiwan FORMOSAT-3/COSMIC six-satellite constellation (Anthes et al., 2008) or the European Meteorological Operational (MetOp) satellite series (Luntama et al., 2008).

The use of RO data in numerical weather prediction has improved weather forecasting especially in remote and data sparse areas of the globe (e.g., Cardinali, 2009) as well as tropical cyclone track forecasting (e.g., Huang et al., 2005). Moreover, RO can deliver accurate information on the thermal structure and cloud top altitude of convective systems and tropical cyclones as demonstrated recently by Biondi et al. (2012; 2013; 2015). Monthly RO climatologies were recently also used, together with radiosonde and reanalysis data, in a study aiming to detect temperature effects of minor volcanic eruptions over 2001-2010 (Mehta et al., 2015). Due to its characteristics, RO is a potentially valuable technique to study the structure of volcanic clouds and to complement current monitoring systems. In this study we investigate whether the cloud 

structure and influence on short-term climate.

119

\section{Data Sets Used}

\subsection{GNSS Radio Occultation Data}

For this study we used RO temperature profiles processed by the Wegener Center for Climate and Global Change (WEGC) with the Occultation Processing System (OPS) version 5.6 (Schwärz et al., 2013), based on excess phase and orbit data version 2010.2640 from the University Corporation for Atmospheric Research (UCAR). The data have a vertical resolution of about $100 \mathrm{~m}$ in the lower troposphere to about $1 \mathrm{~km}$ in the stratosphere (Gorbunov et al., 2004). The quality of RO measurements is best in the Upper Troposphere and Lower Stratosphere (UTLS) with an accuracy of $0.7 \mathrm{~K}$ to $1 \mathrm{~K}$ between $8 \mathrm{~km}$ and $25 \mathrm{~km}$ for individual temperature profiles (Scherllin-Pirscher et al., 2011).

RO data from the following RO missions were used: CHAllenging Minisatellite Payload (CHAMP) (Wickert et al., 2001), Satélite de Aplicaciones Científicas (SAC-C) (Hajj et al., 2004), Gravity Recovery And Climate Experiment (GRACE-A) (Beyerle et al., 2005), FORMOSAT-3/COSMIC, MetOP, and TerraSAR-X (Wickert et al., 2009). RO data from different missions are highly consistent and agree within $0.2 \mathrm{~K}$ between $4 \mathrm{~km}$ and $35 \mathrm{~km}$ for temperature (Scherllin-Pirscher et al., 2011), which allows merging of the data without any calibration or homogenization (Foelsche et al., 2011; Steiner et al., 2011). Available RO data products include individual profiles as well as gridded climatologies (e.g., Ho et al., 2012; Steiner et al., 2013).

\subsection{AIRS and OMI Data}

We used ash observations from AIRS and $\mathrm{SO}_{2}$ observations from OMI to identify volcanic clouds and to differentiate between volcanic ash clouds and $\mathrm{SO}_{2}$ clouds (see section 4.1). AIRS is a thermal infrared (IR) sensor (Aumann et al., 2003) on-board the Aqua satellite, OMI is an ultraviolet-visible (UV-Vis) spectrometer (Levelt et al., 2006) onboard Aura. Both polar orbiting satellites operate in nadir mode (with footprints of $15 \mathrm{~km}$ in diameter and of $13 \mathrm{~km} \times 24 \mathrm{~km}$, 
respectively). AIRS measures the spectrum of the thermal radiation emitted by the Earthatmosphere system (at wavelengths from $0.4 \mu \mathrm{m}$ to $1.0 \mu \mathrm{m}$ and from $3.7 \mu \mathrm{m}$ to $15.4 \mu \mathrm{m}$, during day and night). OMI measures the solar irradiance spectrum (i.e., light backscattered by the atmosphere or reflected by the Earth during daytime) at wavelengths from $270 \mathrm{~nm}$ to $400 \mathrm{~nm}$, where $\mathrm{SO}_{2}$ has strong and distinctive absorption bands. The OMI $\mathrm{SO}_{2}$ retrieval (Yang et al., 2007) provides integrated $\mathrm{SO}_{2}$ concentrations expressed in Dobson Units $\left(1 \mathrm{DU}=2.69 \times 10^{16}\right.$ molecules $\left./ \mathrm{cm}^{2}\right)$.

A selective detection of ash from AIRS is used in this study based on a robust volcanic ash detection method (Clarisse et al., 2013) differentiating ash from clouds, sand and other dust. The AIRS ash index detection has three levels of confidence (low, medium, high). A pixel with a high level of confidence indicates that the presence of ash is almost certain. Note that the ash concentration is not provided and that this very selective ash detection is not effective for low ash concentrations. More details about ash and $\mathrm{SO}_{2}$ products and their limitation are reported by Brenot et al. (2014).

\subsection{CALIPSO Data}

We used level 1 total attenuated backscatter products from CALIOP (CAL_LID_L1, version V3.01). CALIOP is a two wavelength $(532 \mathrm{~nm} / 1064 \mathrm{~nm})$ lidar onboard the CALIPSO satellite with a vertical resolution of $30 \mathrm{~m} / 60 \mathrm{~m}$ and a horizontal resolution of $330 \mathrm{~m} / 1000 \mathrm{~m}$, respectively, in the UTLS up to $20 \mathrm{~km}$ altitude (Winker et al., 2009). CALIOP attenuated backscatter data were used for detecting the ash cloud altitude with high accuracy. The altitude where the attenuated backscatter at $532 \mathrm{~nm}$ is, from top downward, starting to be larger than the background noise is considered to be the cloud top altitude.

\subsection{MODIS Data}

MODIS is an imaging spectroradiometer flying aboard the Terra and Aqua spacecraft. The wide spectral range of MODIS allows monitoring physical and optical cloud properties with global coverage (King et al., 2013). We used NASA MODIS Atmosphere Images Hi-Res Global Mosaic cloud data for defining clear air conditions and conditions with deep convection by using the cloud top pressure (MYD06_L2 and MOD06_L2) as reference (http://modisatmos.gsfc.nasa.gov/index.html). 


\section{Study Cases and Methods}

\subsection{Volcanic Eruption Events}

We have analyzed two eruptions with different characteristics as respective study cases: the Puyehue eruption in 2011, which was mainly an ash eruption, and the Nabro eruption in 2011, which was mainly an $\mathrm{SO}_{2}$ eruption. Puyehue erupted on 5 June 2011 in Chile $\left(40.35^{\circ} \mathrm{S}, 72.07^{\circ} \mathrm{W}\right)$. This eruption affected the Southern Hemisphere with its ash cloud spreading 360 degrees in longitude and finishing its first circle around the globe on 18 June 2011. Several flights in the Southern Hemisphere were cancelled due to the ash in the atmosphere.

During the night of 12 to 13 June 2011 an explosive eruption occurred at the Nabro volcano located in Eritrea $\left(13.37^{\circ} \mathrm{N}, 41.70^{\circ} \mathrm{E}\right)$. This has been recognized as the largest stratospheric sulfur injection since Pinatubo (1991) (Bourassa et al., 2012; Robock, 2013), spreading mainly $\mathrm{SO}_{2}$ in the atmosphere more than 60 degrees in latitude and more than 100 degrees in longitude within a few days and lasting for more than 15 days.

\subsection{Methods}

For the selected eruption cases we first located the ash and $\mathrm{SO}_{2}$ clouds using the AIRS ash index (considering high level of confidence only) and $\mathrm{OMI} \mathrm{SO}_{2}$ data, respectively, as illustrated in Fig. 1 (left panels). In a second step, we screened all RO profiles at mean tangent point locations and selected those located within the region of the volcanic cloud as defined from AIRS and OMI data for each day after the eruption. Over a time period of 20 days from the eruption we found a total of 1109 profiles co-located with the Puyehue cloud, and 248 profiles co-located with the Nabro cloud, respectively.

For detecting the cloud top altitude and for analyzing the volcanic cloud structure we applied the anomaly technique developed by Biondi et al. (2013) for cloud top detection of convective (water) cloud systems and cyclones. We computed the bending angle anomaly by comparing each selected RO bending angle profile in the volcanic cloud area to the monthly RO reference climatology for the same area, i.e., subtracting the RO reference climatology profile from the individual profile and then normalizing with respect to the monthly reference climatology in 
order to obtain a fractional (percentage) anomaly profile. The cloud top altitude is represented as pronounced anomaly in the vertical bending angle structure.

The criterion chosen for cloud top detection is a bending angle anomaly variation larger than $3 \%$ within a $2 \mathrm{~km}$ altitude range, in line with the experience from previous studies (Biondi et al., 2013; 2015) and as found robust in sensitivity tests. We also computed the corresponding temperature anomaly profiles in order to assess the impact of the volcanic cloud on the atmospheric thermal structure. The reference climatologies for bending angle and temperature were obtained by averaging all RO profiles collected in the period 2001 to 2012 to monthly means, using a resolution (i.e., averaging cell size) of $5^{\circ} \times 5^{\circ}$ in latitude and longitude, with about 100 to 400 profiles averaged per grid cell (the specific number depending on month and latitude). The climatology is provided at a vertical sampling grid of 100 meters sampled at $1^{\circ} \mathrm{x}$ $1^{\circ}$ in latitude and longitude.

The cloud top altitude detected with RO was validated by using co-located CALIOP cloud top data from attenuated backscatter within a spatial distance of $200 \mathrm{~km}$. Although no CALIOP measurements are available for the first days of the Puyehue and Nabro eruptions, we found three RO-CALIOP co-locations for the Nabro cloud and seven RO-CALIOP co-locations for the Puyehue cloud for the period 15-19 June 2011.

\section{Results and Discussion}

The results show that in case of both, ash and $\mathrm{SO}_{2}$ volcanic clouds, the applied anomaly technique works well. Figure 1 (top-right) presents volcanic cloud top altitudes detected from RO observations for the investigated eruption cases of Puyehue and Nabro. The monthly climatological tropopause in the respective regions is at $10.8 \mathrm{~km}$ and $17.1 \mathrm{~km}$ altitude, respectively, as computed from RO data (Rieckh et al., 2014). The detection of cloud top altitudes with RO is confirmed with highly accurate reference data from CALIOP observations in Fig. 1 (bottom right). The comparison of cloud top altitudes from RO with co-located CALIOP observations shows good agreement for Nabro and Puyehue with a correlation coefficient of 0.94 and a root mean square (r.m.s.) error of $930 \mathrm{~m}$. Though only 10 co-location pairs were available for this comparison, the r.m.s. error is still quite favorable and fully consistent with the findings for tropical cyclones and convective systems (Biondi et al., 2012, 
2013) and reflects the co-location criterion of $200 \mathrm{~km}$ and the different vertical resolution of the observation methods.

In Figure 2 we show the temperature and bending angle anomaly profiles before (left panels) and after (right panels) the Puyehue and Nabro eruptions as examples of ash and $\mathrm{SO}_{2}$ cloud effects, respectively. The vertical structure of RO temperature anomaly profiles for the Puyehue eruption (Fig. 2b) reveals a prominent cooling of about $-2 \mathrm{~K}$ by the volcanic cloud at about $11 \mathrm{~km}$ in agreement with the findings of previous studies with meteorological satellite data (Woods and Self, 1992; Woods et al., 1995) and with a small number of RO data (Wang et al., 2009; Okazaki and Heki, 2012). The cooling corresponds with a strong positive anomaly in bending angle (Fig. 2d). However, it is not possible to discriminate between volcanic ash clouds and convective clouds from RO only, since the cloud top cooling is common for all convective processes (Biondi et al., 2012, 2013, 2015). For the Puyehue eruption (ash cloud), we thus detected the cloud top altitude, but we did not find any clear signature of the volcanic ash in the RO profile. For discrimination of the clouds, additional information on ash is therefore needed, as used in this study.

For the Nabro eruption the analysis was more complex because of the emission of significant amounts of $\mathrm{SO}_{2}$. Also the atmospheric structure was at the same time affected by the presence of a low tropospheric aerosol cloud influencing the mid-tropospheric temperatures. The tropospheric inversion feature near $6 \mathrm{~km}$ altitude in the Nabro case before and after the eruption (Fig. 2 e,f) is a persistent feature from May to September and is due to dust clouds from premonsoon dust storm activity (e.g., Posfai et al., 2012; Alharbi et al., 2013). We validated this feature in the RO profiles with aerosol cloud top altitude information from CALIOP backscatter data and found the cloud top altitudes consistent for all investigated months (see also Figs. 3 to 5).

RO temperature anomaly profiles (Fig. 2e) and bending angle anomaly profiles (Fig. 2g) just before the eruption (1 June to 11 June 2011) in the area of Nabro $\left(10^{\circ} \times 10^{\circ}\right.$ in latitude and longitude) show a negative temperature anomaly of about $2.5 \mathrm{~K}$ at about $17 \mathrm{~km}$, which occurs close to the monthly climatological tropopause level (black dashed line).

During the Nabro eruption we detected the cloud top altitude and, furthermore, we also found a clear signature distinguishing the eruption itself as shown in Fig. $2 \mathrm{f}$ for temperature and in 
Fig. $2 \mathrm{~h}$ for bending angle anomaly profiles co-located with the volcanic cloud (in a $5^{\circ}$ x $5^{\circ}$ box) just after the eruption. A warm anomaly of nearly $4 \mathrm{~K}$ above the monthly climatological tropopause appears as the eruption signature. The volcanic cloud tops (bending angle anomaly peaks) correspond in this case to the primary tropopause (pink area) and the tropopause itself corresponds to the secondary tropopause (cyan area). These results show that also in the case of volcanic eruptions, as for tropical cyclones (Biondi et al., 2015) and convective systems (Biondi et al., 2012), a double tropopause feature is found, where the lower level is caused by the cloud top and the higher level represents the actual tropopause, which is pushed up by the strength of the eruption.

The Nabro eruption cloud tops are located at a mean altitude of $16.3 \mathrm{~km}$ (Fig. 2f,h, violet dashed line), which is below the climatological tropopause of $17.1 \mathrm{~km}$ (Fig. 2f,h, black dashed line). The warming in the lower stratosphere appears just after the eruption, suggesting that the $\mathrm{SO}_{2}$ cloud directly reached the stratosphere as reported also by Fromm et al. (2013), Vernier et al. (2013) and Fromm et al. (2014) and that its direct radiative effect induced a stratospheric heating. This is different from the Puyehue case where there was no $\mathrm{SO}_{2}$ but an ash cloud which induced a cooling rather than a warming.

The question that arises is whether these thermal structures are really different and distinguishable from normal atmospheric conditions. Figure 3 provides an overview on the atmospheric structure under climatological conditions showing the monthly mean temperature and bending angle anomalies for May 2007-2013 and June 2007-2013 for the areas of Puyehue and Nabro. In the Puyehue region, monthly mean temperature anomalies are within about $\pm 1.5 \mathrm{~K}$. In the Nabro region, the monthly mean temperature anomaly in the UTLS reaches colder values in May (about $-2 \mathrm{~K} \pm 1.5 \mathrm{~K}$ ) than in June (about $1 \mathrm{~K} \pm 1.5 \mathrm{~K}$ ) due to higher convective activity.

In Fig. 4 we furthermore show the situation for the areas of Puyehue and Nabro in June 2010, one year before the eruptions when no volcanic clouds were present. We analyzed the meteorological conditions for both areas using MODIS data. We selected profiles in a deepconvective environment (green) and in a non-deep-convective environment (blue) (denoting here cloudy profiles with cloud top altitude lower than $300 \mathrm{hPa}$ or clear sky). Figure 4 shows that the June 2010 mean anomalies are similar to the climatological means. Temperature and bending 
angle anomalies are larger in the presence of deep convective clouds while they are smaller in the absence of deep convective clouds and do not differ that much from the climatology. In the Nabro area it was very convective from 1 June to 11 June 2011 explaining why the temperature profiles before the eruption show very cold anomalies (see Fig. 2e). Moreover, it is shown that in the Nabro area the tropospheric inversion at about $6 \mathrm{~km}$ altitude is also present in May and June monthly means (Fig. 3b) and in June 2010 under normal conditions (no volcanic eruptions) (Fig. 4b).

Overall we find from Figs. 2 to 4 clear evidence that the mean anomaly profiles after volcanic eruptions show a significantly different structure than those under climatological conditions. There occurs a significant cooling of about $2 \mathrm{~K}$ in the mean after the Puyehue eruption (ash cloud) and a significant warming of about $4 \mathrm{~K}$ in the mean after the Nabro eruption $\left(\mathrm{SO}_{2}\right.$ cloud).

The evolution of the atmospheric structure from May 2011 to December 2011 in the Nabro area (Fig. 5) shows that the stratospheric warming in the area of the volcano remained for several months. In May the average temperature anomaly in the UTLS was about $-1 \mathrm{~K}$. In June before the eruption (green profiles) the average temperature anomaly reached about $-2.5 \mathrm{~K}$, but just after the eruption (red profiles) the trend became opposite with a temperature anomaly of about $4 \mathrm{~K}$ in the mean, and of up to $10 \mathrm{~K}$ for individual profiles. The positive stratospheric temperature anomaly in the Nabro area persisted until October 2011 and then decreased.

Nabro injected about $1.5 \mathrm{Mt} \mathrm{SO}_{2}$ into the stratosphere that caused an enhancement of stratospheric (hydrated sulfate) aerosol (Bourassa et al., 2012; Robock, 2013). Extended aerosol layers up to $20 \mathrm{~km}$ altitude were measured for several months after the eruption, for the first few weeks confined over North Africa and the monsoon region due to the monsoon anticyclonic vortex and then spread over the larger Northern Hemisphere, causing warming of the lower stratosphere (Bourassa et al., 2012). This aerosol enhancement likely explains the warming in the Nabro region over a few months after the eruption as seen in Fig. 5.

\section{Conclusions}


Cloud structure and cloud top height are key parameters for the monitoring of volcanic cloud movement and for characterizing eruptive processes and understanding the impact on short-term climate variability.

We introduced a technique that uses as a first step observations in the thermal infrared (AIRS) and UV-visible (OMI) for identifying volcanic ash and $\mathrm{SO}_{2}$ clouds and for discriminating against water clouds. In a second step we use observations from GNSS RO for detecting the cloud top altitude and for analyzing the volcanic cloud structure. We demonstrated that the anomaly technique developed by Biondi et al. $(2012$; 2013) for detecting cloud tops of convective systems and tropical cyclones can also be used for detecting and monitoring volcanic cloud tops.

Volcanic ash clouds and $\mathrm{SO}_{2}$ clouds have a different impact on the atmospheric thermal structure. Our results revealed a cooling of about $2.5 \mathrm{~K}$ near the cloud top for ash clouds, confirming previous findings. In contrast, we found a clear warming signature from $\mathrm{SO}_{2}$ (and hydrated sulfate) clouds after the eruption of Nabro, with mean amplitudes of about $4 \mathrm{~K}$ just after the eruption and persisting for a few months.

From this encouraging evidence we conclude that, due to their independence from weather conditions and due to their high vertical resolution, RO observations can valuably contribute to improve detection and monitoring of volcanic clouds and to support warning systems. The high accuracy and vertical resolution of RO observations for detecting the tropopause with global coverage will also help to understand whether eruptions overshoot into the stratosphere and contribute to short-term climate variability.

Several new RO missions are planned for the near future, like the COSMIC-2 constellation and further RO receivers in the European MetOp and Chinese FY3 meteorological satellite series. These, together with a much higher number of GNSS signals from the U.S. GPS, the Russian Globalnaya navigatsionnaya sputnikovaya sistema (GLONASS), the European Galileo system, and the Chinese Bei-Dou system will provide RO profiles with unprecedented coverage in space and time for monitoring the thermal structure impacts of volcanic eruptions and their cloud dispersions at any stage.

\section{Acknowledgements}


UCAR/CDAAC (Boulder, CO, USA) is thanked for providing access to its RO excess phase and orbit data, ECMWF (Reading, UK) for access to its analysis and short-term forecast data. We thank the WEGC processing team members for OPS development and for OPSv5.6 RO data. RO data and the reference climatology used for this study are available at WEGC (via www.wegcenter.at) and from the corresponding author (R.B.) on request. The research leading to these results has received funding from the People Programme (Marie Curie Actions) of the European Union's Seventh Framework Programme (FP7/2007-2013) under REA grant agreement $\mathrm{n}^{\circ}$ 328233. The authors thank L. Clarisse (ULB, Belgium) for providing ash estimations.

\section{References}

Alharbi, B. H., Maghrabi, A. and Tapper N.: The March 2009 Dust Event in Saudi Arabia: Precursor and Supportive Environment, B. Am. Meteorol. Soc., 94, 515-528, doi: http://dx.doi.org/10.1175/BAMS-D-11-00118.1, 2013.

Anthes, R. A., Bernhardt, P. A., Chen, Y., Cucurull, L., Dymond, K. F., Ector, D., Healy, S., Ho, S.-P., Hunt, D., Kuo, Y.-H., Liu, H., Manning, K., McCormick, C., Meehan, T. K., Randel, W., Rocken, C., Schreiner, W. S., Sokolovskiy, S. V., Syndergaard, S., Thompson, D. C., Trenberth, K. E., Wee, T. K., Yen, N. L., and Zeng, Z.: The COSMIC/Formosat/3 mission: Early results, B. Am. Meteorol. Soc., 89, 313-333, doi: http://dx.doi.org/10.1175/BAMS-89-3-313, 2008.

Anthes, R. A.: Exploring Earth's atmosphere with radio occultation: contributions to weather, climate and space weather, Atmos. Meas. Tech., 4, 1077-1103, doi:10.5194/amt-4-1077-2011, 2011.

Aumann, H. H., Chahine, M. T., Gautier, C., Goldberg, M-. D., Kalnay, E., McMillin, L. M., Revercomb, H., Rosenkranz, P. W., Smith, W. L., Staelin, D. H., Strow, L. L., and Susskind, J.: AIRS/AMSU/HSB on the Aqua mission: design, science objectives, data products, and processing systems, IEEE T. Geosci. Rem. Sens., 41, 253-264, doi: 10.1109/TGRS.2002.808356, 2003. 
Beyerle, G., Schmidt, T., Michalak, G., Heise, S., Wickert, J., and Reigber, C.: GPS radio occultation with GRACE: Atmospheric profiling utilizing the zero difference technique, Geophys. Res. Lett., 32, L13806, doi:10.1029/2005GL023109, 2005.

Biondi R., Randel, W. J., Ho, S.-P. , Neubert T. and Syndergaard, S.: Thermal structure of convective clouds derived from GPS radio occultations, Atmos. Chem. Phys., 12, 5309-5318, doi:10.5194/acp-12-5309-2012, 2012.

Biondi R., Ho, S.-P., Randel, W. J., Neubert T. and Syndergaard, S.: Tropical cyclone cloud-top height and vertical temperature structure detection using GPS radio occultation measurements, J. Geophys. Res. Atmos., 118, 5247-5259, doi: 10.1002/jgrd.50448, 2013.

Biondi, R., Steiner, A. K., Kirchengast, G., and Rieckh, T.: Characterization of thermal structure and conditions for overshooting of tropical and extratropical cyclones with GPS radio occultation, Atmos. Chem. Phys., 15, 5181-5193, doi:10.5194/acp-15-5181-2015, 2015.

Bourassa, A. E., Robock, A., Randel, W. J., Deshler, T., Rieger, L. A., Lloyd, N. D., Llewellyn, E. J., and Degenstein, D. A.: Large volcanic aerosol load in the stratosphere linked to asian monsoon transport, Science, 337, 78-81, doi: 10.1126/science.1219371, 2012.

Bourassa, A. E., Robock, A., Randel, W. J., Deshler, T., Rieger, L. A., Lloyd, N. D., Llewellyn, E. J., and Degenstein, D. A.: Response to comment on "Large volcanic aerosol load in the stratosphere linked to asian monsoon transport", Science, 339, 647, doi: 10.1126/science.1227961, 2013.

Brenot, H., $\quad$ Theys, N., $\quad$ Clarisse, L., $\quad$ van Geffen, J., $\quad$ van Gent, J., $\quad$ Van Roozendael, M., van $\operatorname{der}$ A, R., Hurtmans, D., Coheur, P.-F., Clerbaux, C., Valks, P., Hedelt, P., Prata, F., Rasson, O., Sievers K., and Zehner, C.: Support to Aviation Control Service (SACS): an online service for near-real-time satellite monitoring of volcanic plumes, Nat. Hazards Earth Syst. Sci., 14, 1099-1123, doi:10.5194/nhess-14-1099-2014, 2014.

Cardinali C.: Monitoring the observation impact on the short-range forecast, Q. J. Roy. Meteor. Soc., 135, 239-250, doi:10.1002/qj.366, 2009.

Clarisse, L., Hurtmans, D., Clerbaux, C., Hadji-Lazaro, J., Ngadi, Y., and Coheur P.-F.: Retrieval of sulphur dioxide from the infrared atmospheric sounding interferometer (IASI), Atmos. Meas. Tech., 5, 581-594, doi:10.5194/amt-5-581-2012, 2012. 
Clarisse, L., Coheur, P.-F., Prata, F., Hadji-Lazaro, J., Hurtmans, D., and C. Clerbaux, C.: A unified approach to infrared aerosol remote sensing and type specification, Atmos. Chem. Phys., 13, 2195-2221, doi:10.5194/acp-13-2195-2013, 2013.

Foelsche, U., Scherllin-Pirscher, B., Ladstädter, F., Steiner, A. K., and Kirchengast, G.: Refractivity and temperature climate records from multiple radio occultation satellites consistent within 0.05\%, Atmos. Meas. Tech., 4, 2007-2018, doi:10.5194/amt-4-2007-2011, 2011.

Fromm, M., Nedoluha, G., and Charvat, Z.: Comment on "Large volcanic aerosol load in the stratosphere linked to asian monsoon transport", Science, 339, doi: 10.1126/science.1228605, 2013.

Fromm, M., Kablick III, G., Nedoluha, G., Carboni, E., Grainger, R., Campbell, J., and Lewis, J.: Correcting the record of volcanic stratospheric aerosol impact: Nabro and Sarychev Peak, J. Geophys. Res. Atmos., 119, 10343-10364, 10.1002/2014JD021507, 2014.

Gorbunov, M. E., Benzon, H.-H., Jensen, A. S., Lohmann, M. S., and Nielsen, A. S.: Comparative analysis of radio occultation processing approaches based on Fourier integral operators, Radio Sci., 39, RS6004, doi:10.1029/2003RS002916, 2004.

Hajj, G. A., Ao, B. A., Iijima, B. A., Kuang, D., Kursinski, E. R., Mannucci, A. J., Meehan, T. K., Romans, L. J., de la Torre Juarez, M., and Yunck, T. P.: CHAMP and SAC-C atmospheric occultation results and intercomparisons, J. Geophys. Res., 109, D06109, doi: 10.1029/2003JD003909, 2005.

Harris D. M., and Rose, W. I. J.: Estimating particle size, concentrations, and total mass of ash in volcanic clouds using weather data, J. Geophys. Res., 88, 10969-10983, doi: 10.1029/JC088iC15p10969, 1983.

Ho, S.-P., Hunt, D., Steiner, A. K., Mannucci, A. J., Kirchengast, G., Gleisner, H., Heise, S., von Engeln, A., Marquardt, C., Sokolovskiy, S., Schreiner, W., Scherllin-Pirscher, B., Ao, C., Wickert, J., Syndergaard, S., Lauritsen, K., Leroy, S., Kursinski, E. R., Kuo, Y.-H., Foelsche, U., Schmidt, T., and Gorbunov, M.: Reproducibility of GPS radio occultation data for climate monitoring: Profile-to-profile inter-comparison of CHAMP climate records 2002 to 2008 from six data centers, J. Geophys. Res., 117, D18111, doi:10.1029/2012JD017665, 2012. 
Holasek, R. E. and Self, S.: GOES weather satellite observations and measurements of the May 18, 1980, Mount St. Helens eruption, J. Geophys. Res., 100, 8469-8487, doi: 10.1029/94JB03137, 1995.

Huang, C.-Y., Kuo, Y.-H., Chen, S.-H., and Vandenberghe, F.: Improvements in Typhoon Forecasts with Assimilated GPS Occultation Refractivity, Wea. Forecasting, 20, 931-953, doi: http://dx.doi.org/10.1175/WAF874.1, 2005.

IUGG, Volcanological and meteorological support for volcanic ash monitoring, Statement adopted by the IUGG Bureau on 28 May 2010, Available at http://www.iugg.org/resolutions/IUGG_Statement_VMSVolcAshMonit.pdf

King, M. D., Platnick, S., Menzel, W. P., Ackerman, S. A., and Hubanks P. A.: Spatial and Temporal Distribution of Clouds Observed by MODIS Onboard the Terra and Aqua Satellites, IEEE Trans. Geosci. Remote Sens., 51, 3826-3852, doi: 10.1109/TGRS.2012.2227333, 2013.

Levelt, P. F., Hilsenrath, E., Leppelmeier, G. W., van den Oord, G. H. J., Bhartia, P. K., Tamminen, J., de Haan, J. F., and Veefkind J. P.: Science objectives of the ozone monitoring instrument, IEEE T. Geosci. Rem. Sens., 44, 1199-1208, doi: 10.1109/TGRS.2006.872336, 2006.

Luntama, J.-P., Kirchengast, G., Borsche, M., Foelsche, U., Steiner, A., Healy, S., von Engeln, A., O'Clerigh, E., and Marquardt, C.: Prospects of the EPS GRAS mission for operational atmospheric applications, Bull. Amer. Met. Soc., 89, 1863-1875, doi: http://dx.doi.org/10.1175/2008BAMS2399.1, 2008.

Mehta, S. K., Fujiwara, M., Tsuda, T., and Vernier, J.-P.: Effect of recent minor volcanic eruptions on temperatures in the upper troposphere and lower stratosphere, J. Atmos. SolarTerr. Phys., 129, 99-110, doi: 10.1016/j.jastp.2015.04.009, 2015.

Monitoring volcanic ash from space, ESA report, STM-280, ESA/ESRIN Frascati, Italy.

Okazaki, I. and Heki, K.: Atmospheric temperature changes by volcanic eruptions: GPS radio occultation observations in the 2010 icelandic and 2011 chilean cases, J. Volcanol. Geoth. Res., 245-246, 123-127, doi: 10.1016/j.jvolgeores.2012.08.018, 2012. 
Pósfai, M., Duncan, A., Tompa, E., Freney, E., Bruintjes, R., and Buseck, P. R.: Interactions of mineral dust with pollution and clouds: An individual-particle TEM study of atmospheric aerosol from Saudi Arabia, Atmos. Res., 122, 347-361, http://dx.doi.org/10.1016/j.atmosres.2012.12.001, 2012.

Prata, A. J.: Satellite detection of hazardous volcanic clouds and the risk to global air traffic, Nat. Hazards, 51, 303-324, doi: 10.1007/s11069-008-9273-z, 2008.

Rieckh, T., Scherllin-Pirscher, B., Ladstädter, F., and Foelsche, U.: Characteristics of tropopause parameters as observed with GPS radio occultation, Atmos. Meas. Tech., 7, 3947-3958, doi:10.5194/amt-7-3947-2014, 2014.

Robock, A.: Volcanic eruptions and climate, Rev. Geophys., 38, 191-219, doi: 10.1029/1998RG000054, 2000.

Robock, A.: The latest on volcanic eruptions and climate, Eos, 94, 305-312, doi: 10.1002/2013EO350001, 2013.

Sawamura, P., Vernier, J. P., Barnes, J. E., Berkoff, T. A., Welton, E. J., Alados-Arboledas, L., Navas-Guzmán, F., Pappalardo, G., Mona, L., Madonna, F., Lange, D., Sicard, M., GodinBeekmann, S., Payen, G., Wang, Z., Hu, S., Tripathi, S. N., Cordoba-Jabonero, C., and Hoff, R. M.: Stratospheric AOD after the 2011 eruption of Nabro volcano measured by lidars over the Northern Hemisphere, Environ. Res. Lett. 7, 034013 doi:10.1088/1748-9326/7/3/034013, 2012.

Scherllin-Pirscher, B., Steiner, A. K., Kirchengast, G., Kuo, Y.-H., and Foelsche, U.: Empirical analysis and modeling of errors of atmospheric profiles from GPS radio occultation, Atmos. Meas. Tech., 4, 1875-1890, doi:10.5194/amt-4-1875-2011, 2011.

Schwärz, M., Scherllin-Pirscher, B., Kirchengast, G., Schwarz, J., Ladstaedter, F., Fritzer, J., and Ramsauer, J.: Multi-Mission validation by satellite radio occultation, ESA report, WEGCESA-MMvalRO-2013-FR, 2013.

Settle, M.: Volcanic eruption clouds and the thermal power output of explosive eruptions, J. Volcanol. Geotherm. Res., 3, 309-324, doi:10.1016/0377-0273(78)90041-0, 1978.

Steiner, A. K., Hunt, D., Ho, S.-P., Kirchengast, G., Mannucci, A. J., Scherllin-Pirscher, B., Gleisner, H., von Engeln, A., Schmidt, T., Ao, C., Leroy, S. S., Kursinski, E. R., Foelsche, U., 
Gorbunov, M., Heise, S., Kuo, Y.-H., Lauritsen, K. B., Marquardt, C., Rocken, C., Schreiner, W., Sokolovskiy, S., Syndergaard, S., and Wickert, J.: Quantification of structural uncertainty in climate data records from GPS radio occultation, Atmos. Chem. Phys., 13, 1469-1484, doi:10.5194/acp-13-1469-2013, 2013.

Steiner, A. K., Lackner, B. C., Ladstädter, F., Scherllin-Pirscher, B., Foelsche, U. and Kirchengast, G.: GPS radio occultation for climate monitoring and change detection, Radio Sci., 46, RS0D24, doi:10.1029/2010RS004614, 2011.

Stohl, A., Prata, A. J., Eckhardt, S., Clarisse, L., Durant, A., Henne, S., Kristiansen, N. I., Minikin, A., Schumann, U., Seibert, P., Stebel, K., Thomas, H. E., Thorsteinsson, T., Tørseth, K., and Weinzierl, B.: Determintation of time- and height-resolved volcanic ash emission and their use for quantitative ash dispersion modeling: the 2010 Eyjafjallajökull eruption, Atmos. Chem. Phys., 11, 4333-4351, doi:10.5194/acp-11-4333-2011, 2011.

Theys, N., Campion, R., Clarisse, L., Brenot, H., $\quad$ van Gent, J., Dils, B., Corradini, S., Merucci, L., Coheur, P.-F., Van Roozendael, M., Hurtmans, D., Clerbaux, C., Tait, S., and Ferrucci, F.: Volcanic SO2 fluxes derived from satellite data: a survey using OMI, GOME-2, IASI and MODIS, Atmos. Chem. Phys., 13, 5945-5968, doi:10.5194/acp-13-5945-2013, 2013.

Tupper, A., Carn, S., Davey, J., Kamada, Y., Potts, R., Prata, F., and Tokuno, M.: An evaluation of volcanic cloud detection techniques during recent significant eruptions in the western “Ring of Fire”, Remote Sens. Environ., 91, 27-46, doi: 10.1016/j.rse.2004.02.004, 2004.

Vernier, J.-P., Fairlie, T. D., Murray, J. J., Tupper, A., Trepte, C., Winker, D., Pelon, J., Garnier, A., Jumelet, J., Pavolonis, M., Omar, A. H., and Powell, K. A.: An advanced system to monitor the 3d structure of diffuse volcanic ash clouds, J. Appl. Meteor. Climatol., 52, 21252138, doi:10.1175/JAMC-D-12-0279.1, 2013.

Vernier, J.-P., Thomason, L. W., Fairlie, T. D., Minnis, P., Palikonda, R. and Bedka, K. M.: Comment on "Large volcanic aerosol load in the stratosphere linked to asian monsoon transport”, Science, 339, doi: 10.1126/science.1227817, 2013. 
Wang, K.-Y., Lin, S.-C., and Lee, L.-C.: Immediate impact of the Mt Chaiten eruption on atmosphere from FORMOSAT-3/COSMIC constellation, Geophys. Res. Lett., 36, L03808, doi:10.1029/2008GL036802, 2009.

Wickert, J., Christoph, R. Beyerle, G., König, R., Marquardt, C., Schmidt, T., Grunwaldt, L., Galas, R., Meehan, T. K., Melbourne, W. G., and Hocke, K.: Atmosphere sounding by GPS radio occultation: First results from CHAMP, Geophys. Res. Lett., 28, 3263-3266, doi: 10.1029/2001GL013117, 2001.

Wickert, J., Schmidt, T., Michalak, G., Heise, S., Arras, C., Beyerle, G., Falck, C., König, R., Pingel, D., and Rothacher, M.: GPS radio occultation with CHAMP, GRACE-A, SAC-C, TerraSAR-X, and FORMOSAT-3/COSMIC: Brief review of results from GFZ, in New Horizons in Occultation Research: Studies in Atmosphere and Climate, A. K. Steiner, B. Pirscher, U. Foelsche, and G. Kirchengast (Eds.), pp. 3-15, Springer, Berlin Heidelberg, doi:10.1007/978-3-642-00321-9_1, 2009.

Winker, D. M., Vaughan, M. A., Omar, A., Hu, Y., Powell, K. A., Liu, Z., Hunt, W. H., and Young, S. A.: Overview of the CALIPSO mission and CALIOP data processing algorithms, J. Atmos. Oceanic Technol., 26, 2310-2323, doi:10.1175/2009JTECHA1281.1, 2009.

Woods, A. W. and Self, S.: Thermal disequilibrium at the top of volcanic clouds and its effect on estimates of the column height, Nature, 355, 628-630, doi:10.1038/355628a0, 1992.

Woods, A. W., Holasek, R. E., and Self, S.: Wind-driven dispersal of volcanic ash plumes and its control on the thermal structure of the plume-top, Bull. Volcanol., 57, 283-292, doi: 10.1007/BF00301288, 1995.

Yang, K., Krotkov, N. A., Krueger, A. J., Carn, S. A., Bhartia, P. K., and Levelt, P. F.: Retrieval of large volcanic SO2 columns from the Aura Ozone Monitoring Instrument (OMI): comparison and limitations, J. Geophys. Res., 112, D24S43, doi:10.1029/2007JD008825, 2007.

Zehner, C. (Ed.), Monitoring volcanic ash from space, Proceedings of the ESA-EUMETSAT workshop on the 14 April to 23 May 2010 eruption at the Eyjafjöll volcano, South Iceland. Frascati, Italy, 26-27 May 2010, ESA-Publication STM-280, doi:10.5270/atmch-10-01, 2010. 
Atmos. Chem. Phys. Discuss., doi:10.5194/acp-2015-974, 2016

Manuscript under review for journal Atmos. Chem. Phys.

Published: 19 January 2016

(c) Author(s) 2016. CC-BY 3.0 License.
Atmospheric

Chemistry

and Physics

Discussions

(c) (i)
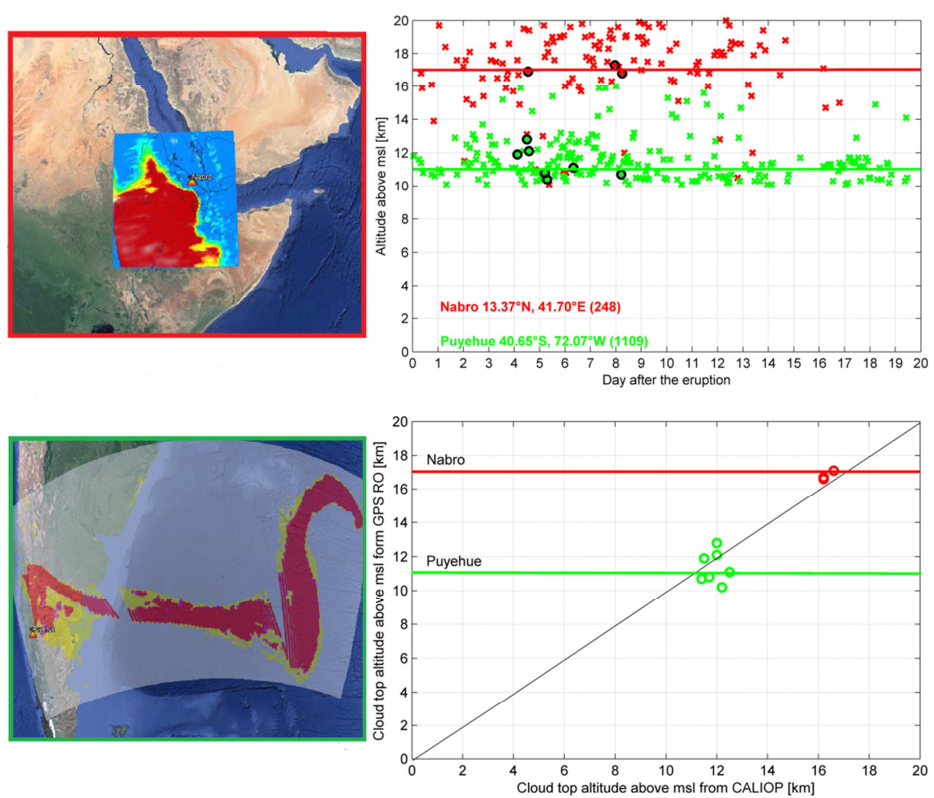

548

549

550

551

552

553

554

555

556

557

Figure 1. (top-left) $\mathrm{SO}_{2}$ cloud from OMI data during the Nabro eruption, and (bottom-left) ash index from AIRS data during the Puyehue eruption. (top-right) Cloud top altitudes of volcanic plumes (cross symbols) for Puyehue (green), and Nabro (red), derived from RO data. (bottomright) Correlation between cloud top altitudes derived from RO with the closest cloud top altitudes from CALIOP (circles). Horizontal solid lines denote the respective monthly climatological tropopause altitudes for the three volcano locations. Numbers in brackets denote the number of RO profiles. 
Atmos. Chem. Phys. Discuss., doi:10.5194/acp-2015-974, 2016

Manuscript under review for journal Atmos. Chem. Phys.

Published: 19 January 2016

(c) Author(s) 2016. CC-BY 3.0 License.

(c) (1)
Atmospheric

Chemistry

and Physics

Discussions
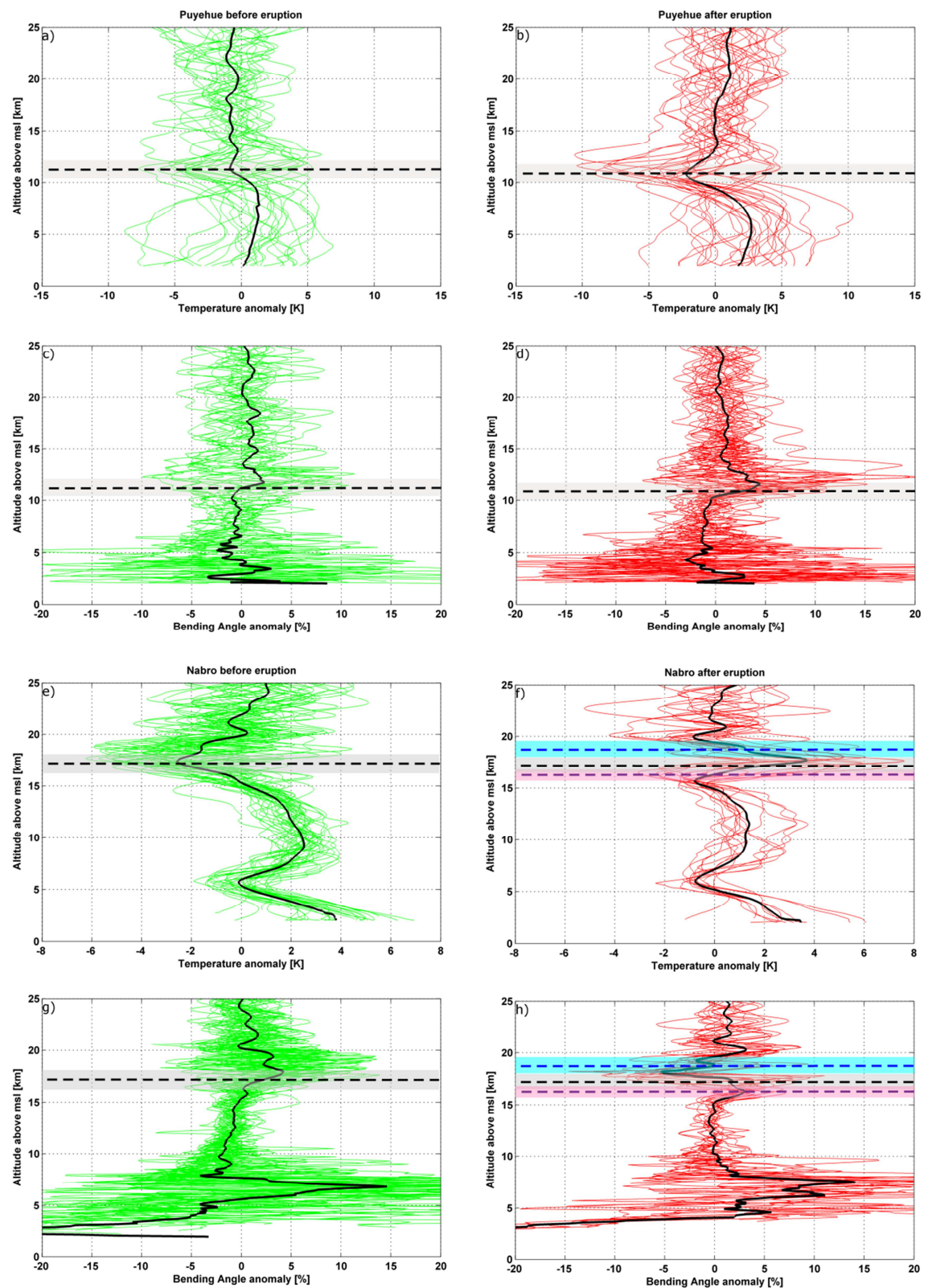

559 Figure 2. Puyehue (top four panels) and Nabro (bottom four panels) cases before (left column) and after (right column) the respective eruption (Puyehue starting 5 June 2011, Nabro 12 June 
Atmos. Chem. Phys. Discuss., doi:10.5194/acp-2015-974, 2016

Manuscript under review for journal Atmos. Chem. Phys.

Published: 19 January 2016

(c) Author(s) 2016. CC-BY 3.0 License.

2011). (a-b) Temperature anomaly profiles and (c-d) bending angle anomaly profiles in the area of Puyehue before (green; May 2011) and after (red; 5-30 June 2011) the eruption, with the aftereruption events co-located with the Puyehue eruptive cloud (AIRS ash index). (e-f) Temperature anomaly profiles and (g-h) bending angle anomaly profiles in the area of Nabro before (green; 111 June 2011) and after (red; 12-20 June 2011) the eruption, with the after-eruption events colocated with the Nabro eruptive cloud $\left(\mathrm{OMI} \mathrm{SO}_{2}\right)$. The mean anomaly profiles (black) and the monthly mean climatological tropopause altitude (horizontal black-dashed lines), plus the associated standard deviation of the individual-profile tropopause altitudes (shaded grey), are also indicated. For the Nabro after-eruption events $(f, h)$ in addition the mean primary tropopause altitude (violet dashed line) and the mean secondary tropopause altitude (blue dashed line) are shown, together with the corresponding standard deviations (pink and cyan shaded). 
Atmos. Chem. Phys. Discuss., doi:10.5194/acp-2015-974, 2016

Manuscript under review for journal Atmos. Chem. Phys.

Published: 19 January 2016

(c) Author(s) 2016. CC-BY 3.0 License.
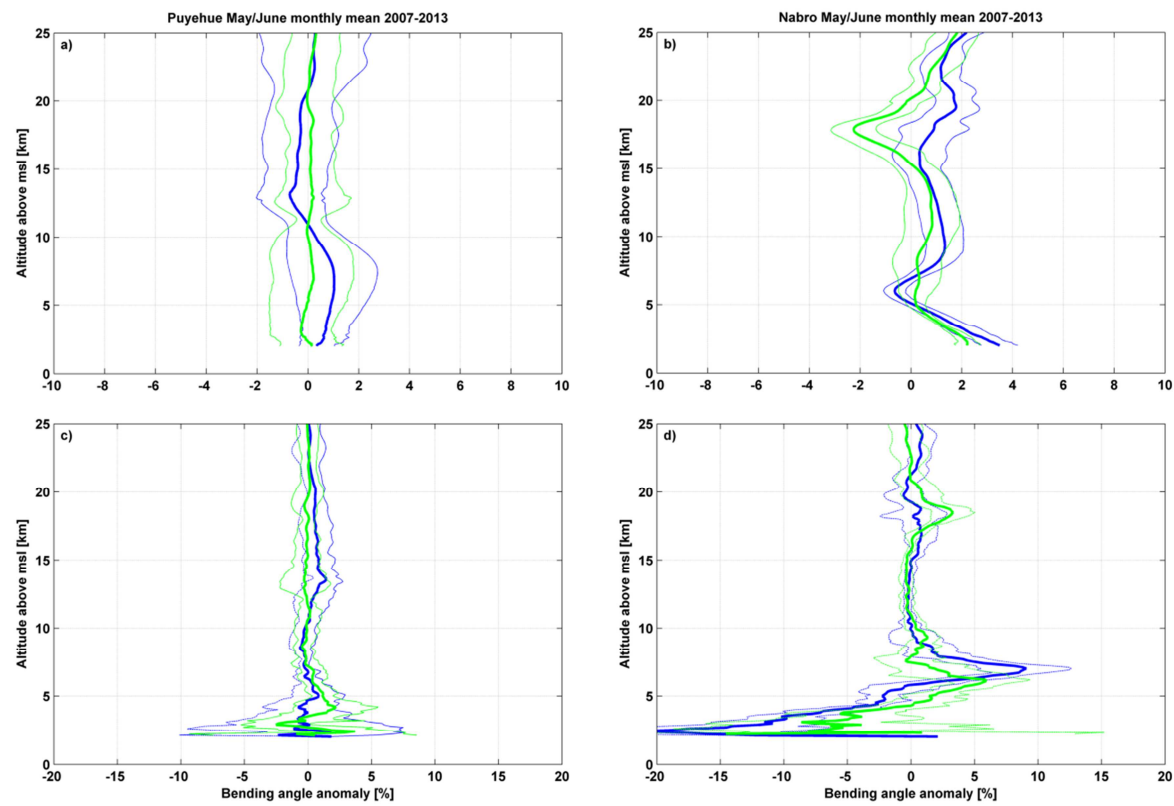

578 Figure 3. Monthly mean temperature anomaly profile (top panels) and bending angle anomaly

579 profile (bottom panels) averaged over May 2007-2013 (heavy green) and June 2007-2013

580 (heavy blue), and standard deviation of the individual monthly-means about this average for May

581 (light green) and June (light blue), in the area of Puyehue (a, c) and Nabro (b, d), respectively.

June 2011, the month of the eruption, is excluded. 
Atmos. Chem. Phys. Discuss., doi:10.5194/acp-2015-974, 2016

Manuscript under review for journal Atmos. Chem. Phys.

Published: 19 January 2016

(c) Author(s) 2016. CC-BY 3.0 License.

(c) (i)
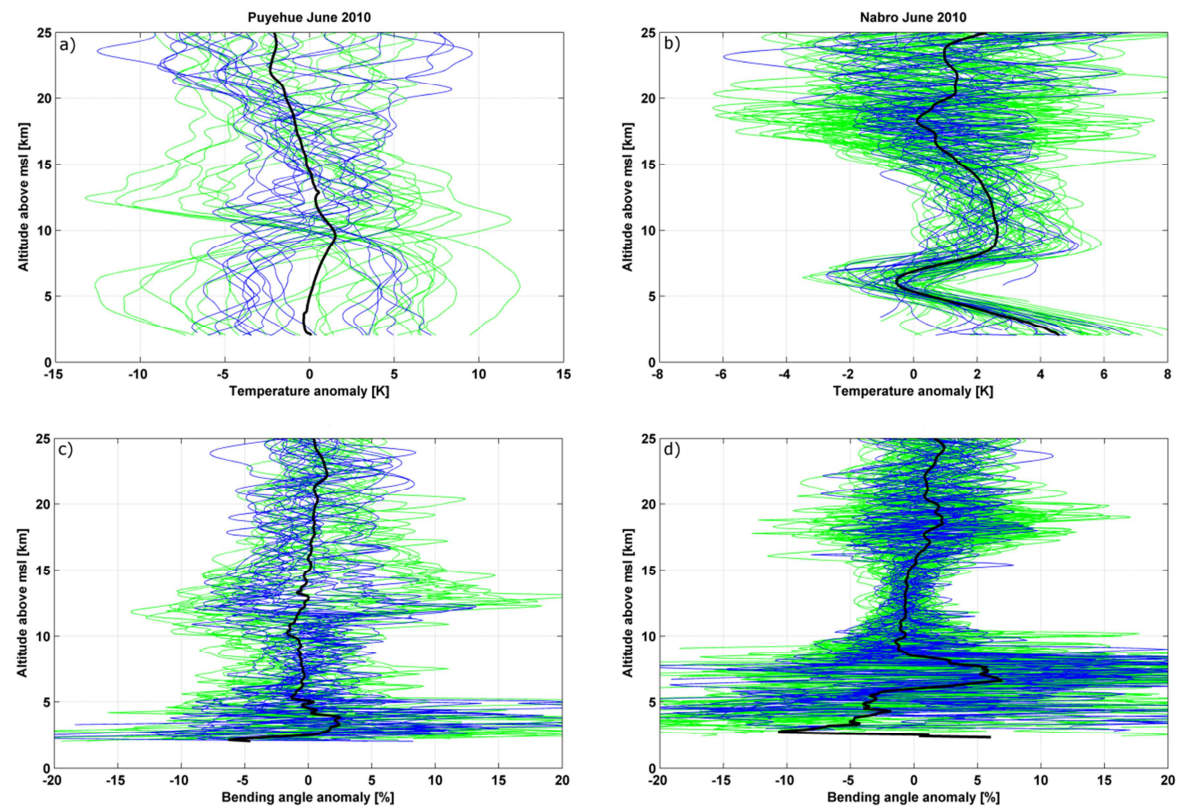

Figure 4. Individual temperature anomaly profiles (top panels) and bending angle anomaly profiles (bottom panels) in deep-convective environment (green), in non-deep-convective environment (blue), and mean anomaly profile for each profile ensemble (black), shown for June 2010 in the area of Puyehue (a, c) and Nabro (b, d), respectively. 
Atmos. Chem. Phys. Discuss., doi:10.5194/acp-2015-974, 2016

Manuscript under review for journal Atmos. Chem. Phys.

Published: 19 January 2016

(c) Author(s) 2016. CC-BY 3.0 License.

(c) (1)
Atmospheric

Chemistry

and Physics

Discussions
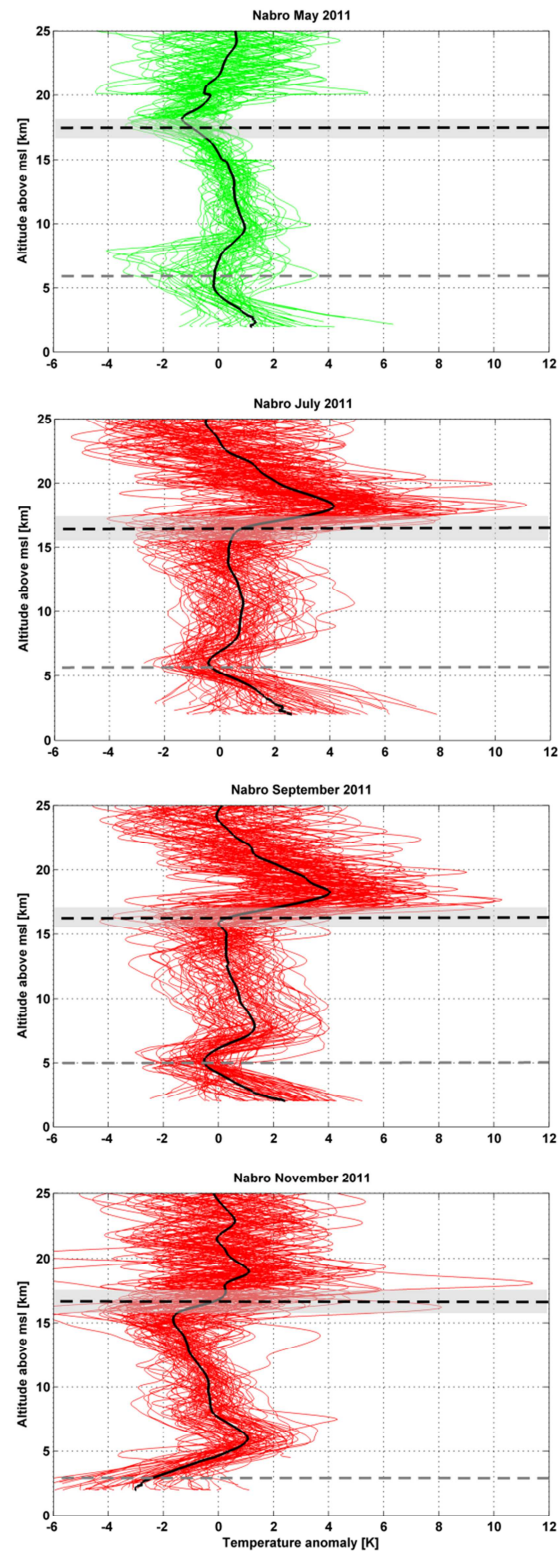
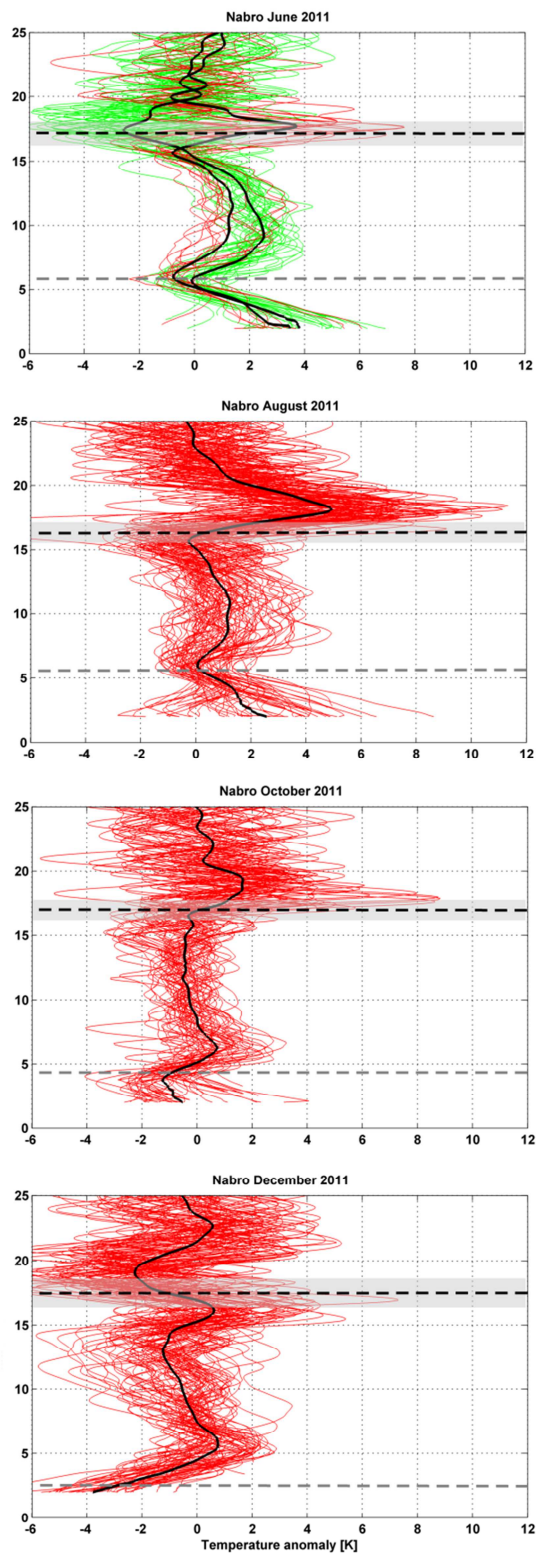

590 Figure 5. Individual temperature anomaly profiles before the eruption (green) and after the eruption (red) with mean anomaly profile (black) in the area of the Nabro volcano $(10 \mathrm{x} 10$ 
Atmos. Chem. Phys. Discuss., doi:10.5194/acp-2015-974, 2016

Manuscript under review for journal Atmos. Chem. Phys.

Published: 19 January 2016

(c) Author(s) 2016. CC-BY 3.0 License.

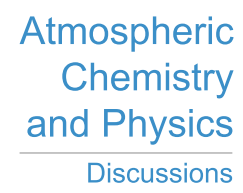

(c) (i)

592 degrees box in latitude and longitude), showing the evolution of the thermal structure from

593 May 2011 to December 2011 (Nabro eruption in June 2011). Climatological tropopause altitude

594 for each month (black dashed line) with its standard deviation (shaded grey). The average

595 altitude of the tropospheric aerosol cloud from CALIOP measurements is indicated in each panel

596 (grey dashed line). 